\title{
An Analysis of Technical Efficiency of Mangrove Rice Production in the Guinean Coastal Area
}

\author{
Boubacar Siddighi Balde ${ }^{1}$, Hajime Kobayashi ${ }^{2}$, Makoto Nohmi ${ }^{2}$, Akira Ishida ${ }^{3}$ Mohamed Esham ${ }^{4}$ \\ \& Emmanuel Tolno ${ }^{1}$ \\ ${ }^{1}$ The United Graduate School of Agricultural Sciences, Tottori University, Tottori, Japan \\ ${ }^{2}$ Faculty of Agriculture, Tottori University, Tottori, Japan \\ ${ }^{3}$ Department of Regional Development, Shimane University, Shimane, Japan \\ ${ }^{4}$ Faculty of Agricultural Sciences, Sabaragamuwa University of Sri Lanka, Belihuloya, Sri Lanka \\ Correspondence: Boubacar Siddighi Balde, The United Graduate School of Agricultural Sciences, Tottori \\ University, Tottori, Japan. Tel: 81-80-4264-8171. E-mail: siddighilonsin@hotmail.com
}

Received: May 9, 2014 Accepted: June 3, 2014 Online Published: July 15, 2014

doi:10.5539/jas.v6n8p179

URL: http://dx.doi.org/10.5539/jas.v6n8p179

\begin{abstract}
In Guinea, the national rice consumption exceeds rice production, leading to concerns about food security. Thus, recent governmental measures have been directed towards promoting rice production, particularly in the coastal areas, the only zone where the mangrove rice production is practiced. Rice is the most important food crop and its production is the most organized food production system in the country. Therefore, it's of interest to examine the efficiency of mangrove rice production, in this study an attempt is made to determine the technical efficiency of mangrove rice production by using the stochastic frontier model. The study used primary data collected through a field survey. The analysis revealed that farm area and depreciation cost of farm tools contribute to significantly enhance the mangrove rice productivity. The inefficiency model revealed that age of household head, household size, farming experience, off-farm income and remittance significantly influenced the technical efficiency. The mean level of the technical efficiency was estimated at $23 \%$, while the efficiency ranged from 0.0 $\%$ to $100 \%$. Furthermore, the analysis indicated that the loss due to the inefficiency was significant with a value of 8,838,762 Guinean Francs per acre. Policy recommendations and strategies for improving the efficiency of mangrove rice production are advocated based on the findings.
\end{abstract}

Keywords: technical efficiency, mangrove rice production, Koba, coastal area, Guinea

\section{Introduction}

Mangrove rice cultivation began in the middle of the eighteenth century in Sierra Leone and Guinea (CEC, 1992). Traditional cultivation practices are still the most widespread and they are followed, for example, in Senegal (the diola system), Guinea Bissau (the bolanha system), Guinea (the Bora-male) and Sierra Leone. The diola and bolanha systems consist of small basins or strips of land that are surrounded by small dikes. Within these "polders" the rice is cultivated on ridges. The tidal rice-cultivation system practiced in the Gambia, Guinea and Sierra Leone consists of flooded rice cultivation during the seasonal period of freshwater flows of the major rivers. The system is tied to the length of the salt-free period. In order to reduce production risks, both the salt-free period and the rice variety should be appropriate. For over 100 years, swamp rice production in West Africa has been undertaken by farmers with limited inputs under adverse saline and acid sulphate conditions. However, some of the fertile soils have been benefited by regular deposits of silt left during annual flooding. The Maritime Guinea or Lower Guinea extends 300 kilometers along the coast and covers an area of $47,400 \mathrm{~km}^{2}$, making it the largest in the West Africa (GRG, 2002).

In Guinea, the coastal lands play a key role in the national food security in terms of agricultural production focused on the mangrove rice farming and over one-third of the country's population live in coastal lands. The promotion of rice growing is one of the priorities of agricultural policy in Guinea (MAL, 2009). Rice is the most important food crop and its production is the most organized crop production system in the country. In 2000, rice production covered $42 \%$ of the total farmland (about 700,000 hectares) for a total production of 700,000 tons of paddy (Barry, 2006). In 2003, the local rice sector generated about 340 billion Guinean francs (GNF) (\$67 
million), which accounted for 5\% of the gross domestic product. Prior to the 1950s Guinea was the third largest rice producer in Africa, after Egypt and Madagascar (Portères, 1966).

In Guinea, rice cultivation is practiced under four majors cropping systems: (1) The traditional rain-fed rice farming is still known as dry rice farming and is by far the most widespread (65\% of the cultivated area). It is carried out on hillsides, in the mountains, and on forest areas after slash and burning. Cultivation is done manually and no fertilizer is used. Yields vary from 500 to $900 \mathrm{~kg} / \mathrm{ha}$ depending on natural fertility and availability of rain. (2) The Lowland rice accounts for $10 \%$ of land under rice. Yields range between 1.5 and 2.5 t/ha. Forest Guinea accounts for the largest stretch of lowland compared to the country's other natural regions. (3) The "Upland" rice growing or rice plain along rivers (the term "upland" is used to represent the Upper Guinea region) differ from the dry rice farming, this system is most dominant in Upper Guinea and in the Gaoual/Koundara areas. It accounts for $9 \%$ of the total area under rice cultivation and its yields vary between $500 \mathrm{~kg}$ and $2 \mathrm{t} / \mathrm{ha}$ depending on the water levels of the Niger and its tributaries. It is sensitive to changes in climatic conditions and flood levels. (4) The mangrove rice farming constitutes the use of cleared mangrove forest land for rice production. It represents also plains spread into the mangrove forests where rice is cultivated. Mangrove rice growing represents $16 \%$ of the total rice growing area in Guinea (MAL, 2009). It represents $18 \%$ of the total rice production in the country. The mangrove area is specially located in the Maritime Guinea (Lower Guinea) Region where the mangrove rice farming represents 51\% of cultivated area (Diawara et al., 2011). Due to the wide variability in yield (1.5 to $3.5 \mathrm{t} / \mathrm{ha}$ ), this rice production system is considered as the most important relative to the three rice farming systems mentioned above. The mangrove swamp rice production system is found where the ocean's tidal action causes inundation at high tide and drainage at low tide. Most mangrove swamps experience a salt-free growing period during the rainy season when freshwater floods wash the land and displace tidal flows. Soils are generally more fertile than in other cropping systems, since they benefit from regular deposits of silt during annual flooding. Soil fertility can be maintained when sea water rich in sediment is allowed into the land during the dry season. However, the soils are also characterized by high salinity and sulfate acidity. The mangrove rice production is limited to the coastal area of Guinea.

Guinea was self-sufficient in rice and exported a surplus to other countries in West Africa. In recent years, population growth (3.1\% per year) has threatened Guinea's food security. Despite a doubling in production over the past decade, to 1.47 million tons in 2009 , rice is now imported to meet the rising demand. Imports were estimated at $44 \%$ of the national rice demand in 1995, falling to $25 \%$ in 2000 and rising again to $40 \%$ in 2002 (MAEF, 2007a). To increase food security, the Guinean government plans to introduce rice cultivation on 25,000 more hectares in favorable areas of Lower and Upper Guinea (MAEF, 2007b). It is aimed to boost the production to 2.5 million tons by 2015 . To achieve this, the government collaborates with international partners, invests in roads, bridges and dykes and supports the dissemination of new technologies, such as improved rice varieties and yield-enhancing farming practices.

In Guinea, the national rice consumption exceeds rice production, leading to concerns about food security. Thus, recent governmental measures have been directed to promoting the rice production, particularly in the coastal areas, the only zone where the mangrove rice production is practiced. The government of Guinea (GOG) is supported by many partners, e.g., AFD (French Development Agency), through financing projects that focused on capacity building and rice grower participation in this farming system. In the above context, the status of mangrove rice production has received extensive attention among policy makers and donors.

Technical efficiency in production is defined as the ability of the farmer to produce at the maximum output (frontier production), given the quantities of inputs and production technology (Aigner et al., 1977). Production efficiency is concerned with the relative performance of the process used in transforming inputs into output. The analysis of efficiency is generally associated with the possibility of farms producing a certain optimal level of output from a given bundle of resources or certain level of output at least-cost. The greater the ratio of production output to the factor input, the greater the magnitude of technical efficiency and vice versa. This definition of technical efficiency implies that differences in technical efficiency between farms exist. Variation in technical efficiency of producers might arise from managerial decisions and specific-farm characteristics that affect the ability of the producer to adequately use the existing technology.

However, there is scanty published literature available on aspects of mangrove rice production in Guinea (Adesina \& Zinnah, 1993; Adesina \& Baidu-Forson, 1995; Balde et al., 2013a, 2014a, 2014b), encouraging us to empirically examine important aspects of mangrove rice production. Some of the research questions addressed in this study are; how efficient are mangrove rice farmers in the Guinean coastal area? How significant is the loss due to the inefficiencies? What are the factors determining the inefficiency of the mangrove rice production in Guinea. A pre-requisite for enhanced efficiency is to identify the factors at the farmer-level and other factors that affect the 
efficiency of mangrove rice production. Insights into these factors will enable to come up with effective policies and strategies for enhancing sustainable mangrove rice production. The implication is that there is a scope to increase output from existing farm areas if the efficiency of mangrove rice production is improved. Since increased output and productivity are directly related to production efficiency, the study becomes imperative, as it would identify factors that influence technical efficiency in the mangrove rice production system among farmers. The identification of those factors, which influence the level of technical efficiency, is a valuable exercise because the factors are significant for policy formulation.

\section{Materials and Methods}

\subsection{Study Area and Data Collection}

Koba sub-prefecture is one of the eight sub-prefectures (Tamita, Lisso, CU Boffa [urban commune of Boffa], Douprou, Kolia, Tougnifili and Mankountan) of the Boffa prefecture. It is located hundred kilometers away from the Boffa prefecture, covering an area of $1,026 \mathrm{~km}^{2}$ with a total population of 52,720 inhabitants of which 27,304 are females. Koba is bordered to the North by Tanene sub-prefecture of Dubreka prefecture, to the West by Mara Island in the urban commune of Boffa and to the South-East by the Atlantic Ocean. Koba is the main region in Guinea in terms of salt production and mangrove rice production. The study area is home for the agronomic research center of Koba (CRAK) which specializes in the experimentation of mangrove and freshwater rice varieties. This area has many facilities and infrastructures compared to all other sub-prefectures throughout Guinea.

This study is based on primary cross sectional data collected from three districts (Balessourou, Makinsi and Bentya) located in the Koba sub-prefecture in the Boffa prefecture. These are the major districts in which economic activities such as improved and traditional mangrove rice production are undertaken. Districts were selected based on information obtained from key informants. This purposive sampling was based on advice from experts combined with researchers' judgment and rapid exploratory studies in the study area. A Field survey was conducted from March to April 2013. Structured questionnaire designed to capture information related to the characteristics of mangrove rice farmers, their inputs allocated to the rice cultivation and its output. This questionnaire was administered to 140 respondents belonging to three different groups: 50 traditional mangrove rice (TMR) (Note 1) farmers, 50 improved mangrove rice (IMR) (Note 2) farmers and 40 salt marsh (SM) (Note 3 ) producers. These 40 salt producers were included because they were also cultivating the mangrove rice. It is important to highlight that respondents in each group were randomly selected. Personal interviews and field observations were undertaken to compliment and triangulate the answers provided by the respondents to the questionnaire. Among these 140 farmers listed above, the current study selected only 69 farmers ( 20 from the TMR; 9 from IMR and 40 from SM) considering the fact they hired labor forces and applied agricultural inputs such as fertilizer and pesticide.

\subsection{Empirical Model}

This study applied FRONTIER 4.1 with the trans-log production function for the analysis of technical efficiency. Coelli (1996) had developed the software FRONTIER 4.1, which can be used to generate both the stochastic production frontier and the inefficiency model simultaneously. The FRONTIER 4.1 was widely applied in different fields of research in the past 15 years, especially in agricultural studies (Binuomote et al., 2008; Bakhsh et al., 2006; Bamiro et al., 2006; Battese \& Coelli, 1995). The Stochastic Frontier Approach (Coelli et al., 1998) was used for measurement of technical efficiency. Inefficiency was defined as the distance between a farmer's actual mangrove rice production value and the estimated frontier mangrove rice production value that corresponds to the state of its production technology. Output value, the revenue from mangrove rice production, in Guinean Franc (GNF) was used as the dependent variable since some previous empirical studies have used the monetary value as the dependent variable (Coelli \& Battese, 1996; Aigner et al., 1977). The explanatory variables, used to explain efficiency such as: fertilizer \& pesticide cost (GNF/acre), hired labor cost (GNF/acre), depreciation cost of farm tools (GNF/acre), seed quantity ( $\mathrm{kg} / \mathrm{acre})$, active family labors per family size (\%) and farm area under mangrove rice cultivation (acre), were included in the model measures of technical efficiency. Based on Battese and Coelli (1995) and Coelli et al. (1998), the following model was used:

$$
\ln Y_{i}=\beta_{0}+\sum_{i=1}^{x} \beta_{j} \ln X_{i j}+v_{i}-u_{i}
$$

where, $\mathrm{Y}_{\mathrm{i}}$ is the dependent variable in the production function representing the total production value expressed in GNF of $i^{\text {th }}$ mangrove rice farmers, $\mathrm{X}_{\mathrm{ij}}$ is the $\mathrm{j}^{\text {th }}$ input $(\mathrm{j}=1-6)$ used by $\mathrm{i}^{\text {th }}$ farmer. $\beta_{0}$ is the intercept (constant) and $\beta_{\mathrm{j}}$ are response parameters to be estimated or elasticity corresponding to each input $(\mathrm{j}=1-6)$, including 
fertilizer and/or pesticide cost (GNF/acre), hired labor cost (GNF/acre), depreciation cost on farm tools (GNF/acre), seed quantity ( $\mathrm{kg} / \mathrm{acre}$ ), active family labors per family size (\%) and farm area under mangrove rice cultivation (acre). The estimation of stochastic production frontier functions assumes that the underlying production technology is the same for all firms or common to all productive units (Orea \& Kumbhakar, 2004; Danquah et al., 2013). In line with this assumption, as some farmers applied either only fertilizer or pesticide and others both of these inputs, we combined these two inputs into one variable (fertilizer and/or pesticide). $v_{i}$ and $u_{i}$ are components forming an error term $\left(\varepsilon_{\mathrm{i}}\right) . \mathrm{v}_{\mathrm{i}}$ is the random variable error associated with random factors such as measurement errors and other statistical noise and exogenous factors beyond the producers' control such as natural disasters. $v_{i}$ is assumed to be independently and identically distributed and independent of $u_{i}$. While $u_{i}$ is non-negative random variable associated with farm's specific factors which would affect technical efficiency of salt producers. $u_{i}$ is assumed to be independently truncated-normal distribution with mean $\mu$ and variance $\delta^{2}$. Although $u_{i}$ can also have other distributions, FRONTIER 4.1 computer program used in the study can only harmonize with above assumption. The term $\mu_{\mathrm{i}}$ is defined as follows:

$$
\mu_{i}=\delta_{0}+\delta_{1} Z_{1 j}+\delta_{2} Z_{2 j}+\delta_{3} Z_{3 j}+\delta_{4} Z_{4 j}+\delta_{5} Z_{5 j}+\delta_{6} Z_{6 j}+\delta_{7} Z_{7 j}+\delta_{8} Z_{8 j}+\delta_{9} Z_{9 j}+\delta_{10} Z_{10 j}+\delta_{11} Z_{11 j}+\delta_{12} Z_{12 j}+\omega_{i}
$$

Where, $\mu_{1}$ is the inefficiency effects that could be estimated by 2 stage estimation technique in FRONTIER 4.1 spontaneously. $\delta_{0}$ represents the intercept term, $\delta_{\mathrm{j}}$ is the parameter for $\mathrm{j}^{\text {th }}$ independent variables. $Z_{1 \mathrm{j}}$ is the age of the head of household (years). The variable age may indicate the likelihood of a given mangrove rice farmer (younger or older) to adopt innovations (new ideas and techniques in farming). This variable is also a proxy for experience which represents human capital, revealing that farmers with more years of experience in farming will have more technical skills in management and thus higher efficiency than younger farmers. $Z_{2 j}$ is the education level (number of schooling years). Education and age (proxy for experience) are important variables that help to improve the managerial ability of the farmer and both are expected to contribute positively for the improvement of technical efficiency (Abedullah et al., 2007). It supports the hypothesis that education and experience are important for dealing with rapid change in farming systems. Therefore, both have been included in technical inefficiency effect model (Equation 2). $Z_{3 j}$ is the origin of the farmers which is considered as a dummy variable $\left(1=\right.$ native and $0=$ migrated). $Z_{4 \mathrm{j}}$ represents household size (persons). $Z_{5 \mathrm{j}}$ is the distance from the homestead to rice field $(\mathrm{km})$. Distance from homestead to mangrove rice field captures the frequency of a given farmer's visit to the field. It is reasonable to assume that when this distance is less, more the farmer visits his farm and consequently the farm receives more attention in terms of its management. Therefore, farms located closer to the homestead will be more technically efficient than the once located further away from the homestead. $Z_{6 j}$ represents farming experience of the head of household in mangrove rice production (years). This variable is important for the identification of factors determining the technical efficiency because better experience in mangrove rice cultivation may also enhance critical evaluation of the relevance of better production decisions, including efficient utilization of productive resources. $Z_{7 \mathrm{j}}$ corresponds to usage of improved seeds measured as a dummy variable $\left(1=\right.$ yes and $0=$ otherwise). $Z_{8 \mathrm{j}}$ is off-farm income and remittance considered as the monetary value of the Guinean franc (GNF). $Z_{9 j}$ is extension provided by the government of Guinea (GOG) considered as a dummy variable $(1=$ yes and $0=$ otherwise $) . Z_{10 \mathrm{j}}$ is extension received from NGOs $(1=$ yes and $0=$ otherwise $)$ These variables $\left(Z_{9 j}\right.$ and $\left.Z_{10 j}\right)$ refer to technical assistance from extension personnel provided by local government and NGOs, respectively. The access of mangrove rice farmers to technical assistance may enhance their access to information and use of improved farming techniques. $Z_{11 j}$ represents networking with neighbors for farming advice $(1=$ yes and $0=$ otherwise). This variable is included to capture the influence of social capital that arises from networking with neighbors. $Z_{12 \mathrm{j}}$ is access to credit $(1=$ yes and $0=$ otherwise). A study by Etim and Okon (2013) revealed that the accessibility and availability of credit relax the production constraints and hence makes it easier to timely purchase of resources, thereby increasing productivity through efficiency. $\omega_{\mathrm{i}}$ is an error term (unobservable random variable).

Maximum Likelihood Estimates (MLEs) for all parameters of the stochastic frontier production (Equation 1) and inefficiency model (Equation 2) were simultaneously estimated by using the FRONTIER 4.1 computer program (Coelli, 1996). This program also presented the coefficients of variance parameters: 


$$
\begin{gathered}
\sigma^{2}=\sigma_{v}^{2}+\sigma^{2}{ }_{u} \\
\gamma=\sigma^{2}{ }_{u} / \sigma^{2}{ }_{v} \\
0 \leq \gamma \leq 1
\end{gathered}
$$

where, $\gamma$ parameter gamma shows the share of inefficiency in the overall residual variance and lies between zero and one. If gamma is equal to zero, then it means that all variations of mangrove rice production revenue are due to noise. And if it is equal to one, then it means that all variations are due to technical inefficiency (Coelli \& Battese, 1996). It is worth mentioning here that the above models for the inefficiency effects are stochastic and have a particular distributional specification. Here, it is important to test the following hypotheses: (1) $\mathrm{H}_{0}: \gamma=\delta_{0}$ $=\ldots=\delta_{10}=0$, i.e., inefficiency is absent. (2) $\mathrm{H}_{0} \gamma=0$, i.e., inefficiency effects are not stochastic. (3) $\mathrm{H}_{0}: \delta_{0}=\ldots$ $\delta_{10}=0$, i.e., the coefficients of explanatory variables in the models are simultaneously zero. (4) $\mathrm{H}_{0}: \delta_{1}=\ldots=\delta_{10}$ $=0$, i.e., the coefficients of the variables in the model for inefficiency effects are zero. The tests of these hypotheses for the parameters of the frontier are conducted using the generalized likelihood ratio statistics, $\lambda$ defined as;

$$
\lambda=-2\left[\mathrm{LR}_{R}-\mathrm{LR}_{U}\right]
$$

where, $L_{R}$ is the value of the likelihood function for the frontier model in which parameter restrictions are specified by the null hypothesis and $\mathrm{LR}_{\mathrm{U}}$ is the value of the likelihood function for the general linear frontier model. If the null hypothesis is true, then $\lambda$ has approximately a chi-square (or mixed square) distribution with the degrees of freedom equal to the difference between the parameter estimated under $L_{R}$ and $\mathrm{LR}_{U}$, respectively. The technical efficiency of the mangrove rice farmer, given the specification of the model, is defined by $\mathrm{TE}_{\mathrm{i}}=$ $\mathrm{E}\left(-\mathrm{U}_{\mathrm{i}}\right)$. Thus, the technical efficiency of the mangrove rice farmer lies between zero to one and it is inversely related to the inefficiency model. The parameters of the stochastic frontier production function model are estimated by the method of the maximum likelihood using the Econometric Computer Program, Frontier Version 4.1 (Coelli \& Battese, 1996).

\section{Results and Discussion}

\subsection{Descriptive Statistics of Variables}

The average value of mangrove rice production is higher among IMR farmers, almost twofold of the average value of production by the SM and TMR farmers (Table 1). As expected, farmers under improved mangrove rice farming (IMR and SM) have presented a higher average of total production value than those practicing the traditional mangrove rice (TMR) cultivation. The highest production by IMR farmers can be attributed to the irrigation facility which enables them to manage appropriately the water level and start the rice planting from the beginning of the rainy season.

According to Carr (2013) (Note 4), among the issues concerning with the future welfare of the African continent and its people pertains to the farm size. Many argue that lands should be left in the hands of large scale commercial farmers or a multitude of smallholders. However, experiences from Japan, China, and elsewhere in Asia show us that farm size is not the key determinant of productivity. These farmers obtain levels of productivity per unit area of land which are equal or greater than those achieved by large-scale farmers anywhere in the world. The key to their success is not the size of their land holding but their access to intensive farm inputs and particularly to inorganic fertilizer. This in turn is largely dependent upon the availability of subsidies. In the case of East Asia, subsidies are of a similar level to those provided to European farmers. The comparatively low yields of staple food crops obtained from small-scale farms in Sub-Saharan Africa are not a direct result of the size of their farms, but rather that they only have access to about 5\% of the level of fertilizer per unit area of land as compared to their East Asian counterparts (Carr, 2013).

The mean value of both fertilizer and/or pesticide cost per farm area is statistically significant at the $1 \%$ level. SM farmers have invested more on both fertilizer and pesticide. The mean and maximum of these input costs show higher values 2,678,254 and $1.10 \times 10^{7} \mathrm{GNF}$ respectively. As these SM farmers were also practicing the improved salt production and obtaining significant income from it. This could well explain the higher investment they are making on fertilizer and pesticide than the other group of farmers (TMR and IMR). According to the SNSA (2004a), among 2,272,638 cultivated plots corresponding to 1,370,145 hectares, only $20 \%$ have received organic manures and /or mineral. In addition, $99 \%$ of these cultivated plots were not applied with pesticides. The 
use of modern agricultural farm inputs such as fertilizer, agrochemical; improved seed, etc., is too insignificant in most of Sub-Saharan African countries. This corroborates with a census (Note 5) conducted in Guinea during the 2000-2001 agricultural campaign. For the entire country, the results indicated that: nitrogen fertilizer is applied to $1.5 \%$ of the plots, phosphate fertilizer to $0.5 \%$ of the plots, potassium fertilizer to 0.5 and $0.2 \%$ of plots with triple fertilizer (SNSA, 2004b).

The mean of hired labor cost per farm area among SM farmers is the highest shows. This is line with the previous reasoning related to the income generated from salt production. However, it is important to highlight that the maximum value of hired labor cost per farm area was reported by the TMR farmers. This could be attributed to the presence of some civil servants among the TMR farmers. These civil servants are better off in terms of off-farm income and remittance. Their average (7,617,100 GNF) and maximum $\left(3.40 \times 10^{7} \mathrm{GNF}\right)$ values of off-farm income and remittances were higher than that obtained by SM and IMR farmers.

The overall education level of surveyed peasants remains low, with an average of three years of schooling. However, it is important to note that the mean education level (Table 1) of traditional mangrove rice farmers is above the average of the overall sample. This result confirms the findings of Balde et al. (2014b). This can be explained as there are highly educated farmers among traditional mangrove rice farmers who were formally employed at SAKOBA (Note 6) shrimp farm. After the closure of this industrial farm, these educated persons engaged in mangrove rice farming.

The average distance $(10.33 \mathrm{~km})$ from the mangrove rice field to the homestead of SM farmers exceed the overall average value of $6.70 \mathrm{~km}$ (Table 1). With respect to the IMR and TMR farmers, the mean distances were 1.08 and $1.98 \mathrm{~km}$ respectively. These IMR and TMR farmers were found living in Bentya and Makinsy districts respectively. The locations are almost around the plains adjacent to the mangrove forest. Both average values of farming experience of IMR (31.78 years) and TMR (28.70 years) farmers have exceeded the pooled sample mean of 22.77 years.

Table 1. Summary statistics of the study variables for mangrove rice production

\begin{tabular}{|c|c|c|c|c|c|c|c|}
\hline \multicolumn{3}{|c|}{ Variables and units } & \multirow{2}{*}{$\frac{\text { SM }}{10,855,000}$} & \multirow{2}{*}{$\begin{array}{c}\text { IMR } \\
19,611,111\end{array}$} & \multirow{2}{*}{$\begin{array}{c}\text { TMR } \\
9,896,250\end{array}$} & \multirow{2}{*}{$\begin{array}{c}\text { Total } \\
11,719,202\end{array}$} & \multirow{2}{*}{$\frac{\text { p-value }}{0.000^{* * *}}$} \\
\hline Total production & Guinean & Mean & & & & & \\
\hline value & Franc (GNF) & Std. Error & 752,772 & 928,999 & $1,663,757$ & 752,219 & \\
\hline & & Minimum & $4.20 \times 10^{6}$ & $1.62 \times 10^{7}$ & $2.85 \times 10^{6}$ & $2.85 \times 10^{6}$ & \\
\hline & & Maximum & $1.88 \times 10^{7}$ & $2.30 \times 10^{7}$ & $2.78 \times 10^{7}$ & $2.78 \times 10^{7}$ & \\
\hline \multirow{4}{*}{$\begin{array}{c}\text { Fertilizer and } \\
\text { pesticide cost per } \\
\text { farm area }\end{array}$} & GNF/acre & Mean & $2,678,254$ & 810,241 & 512,998 & $1,806,989$ & $0.000^{* * *}$ \\
\hline & & Std. Error & 332,622 & 215,468 & 288,153 & 244,410 & \\
\hline & & Minimum & 28,340 & 43,725 & 1,336 & 1,336 & \\
\hline & & Maximum & $1.10 \times 10^{7}$ & $1.84 \times 10^{6}$ & $4.22 \times 10^{6}$ & $1.10 \times 10^{7}$ & \\
\hline \multirow{4}{*}{$\begin{array}{c}\text { Hired labor cost } \\
\text { per farm area }\end{array}$} & GNF/acre & Mean & 644,980 & 236,167 & 550,808 & 564,360 & $0.053^{*}$ \\
\hline & & Std. Error & 40,280 & 49,355 & 166,261 & 55,483 & \\
\hline & & Minimum & 242,915 & 20,243 & 30,364 & 20,243 & \\
\hline & & Maximum & $1.13 \times 10^{6}$ & 384,615 & $3.02 \times 10^{6}$ & $3.02 \times 10^{6}$ & \\
\hline \multirow{4}{*}{$\begin{array}{l}\text { Depreciation cost } \\
\text { on farm tools per } \\
\text { farm area }\end{array}$} & GNF/acre & Mean & 78,927 & 28,579 & 59,961 & 66,862 & $0.012^{* *}$ \\
\hline & & Std. Error & 8,376 & 3,493 & 8,708 & 5,823 & \\
\hline & & Minimum & 8,097 & 19,501 & 12,146 & 8,097 & \\
\hline & & Maximum & 177,463 & 45,187 & 154,656 & 177,463 & \\
\hline \multirow{4}{*}{$\begin{array}{l}\text { Seed quantity } \\
\text { per farm size }\end{array}$} & Kg/acre & Mean & 96.24 & 46.30 & 42.67 & 74.20 & $0.000^{* * *}$ \\
\hline & & Std. Error & 8.06 & 7.59 & 5.75 & 5.92 & \\
\hline & & Minimum & 40.49 & 20.24 & 11.74 & 11.74 & \\
\hline & & Maximum & 202.43 & 75.91 & 121.46 & 202.43 & \\
\hline
\end{tabular}




\begin{tabular}{|c|c|c|c|c|c|c|c|}
\hline \multirow{4}{*}{$\begin{array}{c}\text { Active family } \\
\text { labors per family } \\
\text { size }\end{array}$} & \multirow[t]{4}{*}{ percent } & Mean & 79.64 & 69.01 & 63.75 & 73.65 & \multirow[t]{4}{*}{$0.000^{* * *}$} \\
\hline & & Std. Error & 1.37 & 5.23 & 4.14 & 1.79 & \\
\hline & & Minimum & 61.11 & 45.45 & 33.33 & 33.33 & \\
\hline & & Maximum & 100.00 & 88.89 & 93.33 & 100.00 & \\
\hline \multirow{4}{*}{$\begin{array}{l}\text { Farm area under } \\
\text { mangrove rice } \\
\text { cultivation }\end{array}$} & \multirow[t]{4}{*}{ acre } & Mean & 2.44 & 6.31 & 7.60 & 4.44 & \multirow[t]{4}{*}{$0.000^{* * *}$} \\
\hline & & Std. Error & 0.18 & 0.43 & 1.05 & 0.43 & \\
\hline & & Minimum & 1.24 & 4.94 & 1.24 & 1.24 & \\
\hline & & Maximum & 4.94 & 7.41 & 14.82 & 14.82 & \\
\hline \multirow{4}{*}{$\begin{array}{c}\text { Age of household } \\
\text { head }\end{array}$} & \multirow[t]{4}{*}{ years } & Mean & 48.65 & 48.00 & 48.10 & 48.41 & \multirow[t]{4}{*}{0.959} \\
\hline & & Std. Error & 1.10 & 3.39 & 2.16 & 0.98 & \\
\hline & & Minimum & 36.00 & 32.00 & 29.00 & 29.00 & \\
\hline & & Maximum & 60.00 & 67.00 & 67.00 & 67.00 & \\
\hline \multirow[t]{4}{*}{ Education level } & \multirow[t]{4}{*}{ years } & Mean & 2.73 & 0.89 & 5.95 & 3.42 & \multirow[t]{4}{*}{$0.001^{* * *}$} \\
\hline & & Std. Error & 0.46 & 0.56 & 1.14 & 0.48 & \\
\hline & & Minimum & 0.00 & 0.00 & 0.00 & 0.00 & \\
\hline & & Maximum & 9.00 & 5.00 & 18.00 & 18.00 & \\
\hline \multirow[t]{4}{*}{ Family size } & & Mean & 12.48 & 12.56 & 12.25 & 12.42 & \multirow[t]{4}{*}{0.981} \\
\hline & & Std. Error & 0.66 & 1.97 & 1.23 & 0.57 & \\
\hline & & Minimum & 5.00 & 7.00 & 5.00 & 5.00 & \\
\hline & & Maximum & 18.00 & 27.00 & 24.00 & 27.00 & \\
\hline \multirow{4}{*}{$\begin{array}{l}\text { Distance from } \\
\text { mangrove rice } \\
\text { field to } \\
\text { homestead }\end{array}$} & \multirow[t]{4}{*}{$\mathrm{km}$} & Mean & 10.33 & 1.08 & 1.98 & 6.70 & \multirow[t]{4}{*}{$0.000^{* * *}$} \\
\hline & & Std. Error & 0.39 & 0.11 & 0.41 & 0.58 & \\
\hline & & Minimum & 4.00 & 0.75 & 0.50 & 0.50 & \\
\hline & & Maximum & 15.00 & 1.50 & 6.00 & 15.00 & \\
\hline \multirow{4}{*}{$\begin{array}{c}\text { Farming } \\
\text { experience }\end{array}$} & \multirow[t]{4}{*}{ years } & Mean & 17.78 & 31.78 & 28.70 & 22.77 & \multirow[t]{4}{*}{$0.001^{* * *}$} \\
\hline & & Std. Error & 1.27 & 4.61 & 3.81 & 1.60 & \\
\hline & & Minimum & 5.00 & 10.00 & 6.00 & 5.00 & \\
\hline & & Maximum & 46.00 & 52.00 & 80.00 & 80.00 & \\
\hline \multirow{4}{*}{$\begin{array}{l}\text { Off-farm income } \\
\text { and remittance }\end{array}$} & & Mean & 973,800 & $6,194,444$ & $7,617,100$ & $3,580,348$ & \multirow[t]{4}{*}{$0.000^{* * *}$} \\
\hline & & Std. Error & 66,906 & $1,958,323$ & $2,094,742$ & 745,789 & \\
\hline & & Minimum & 450,000 & 750,000 & 0.00 & 0.00 & \\
\hline & & Maximum & $2.55 \times 10^{6}$ & $1.63 \times 10^{7}$ & $3.40 \times 10^{7}$ & $3.40 \times 10^{7}$ & \\
\hline
\end{tabular}

$* * *=$ significant at $1 \%, * *=$ significant at $5 \%$ and $*=$ significant $10 \%$.

Table 1. (Continued)

\begin{tabular}{|c|c|c|c|c|c|c|}
\hline Variables and unit & & SM & IMR & TMR & Total & p-value \\
\hline \multirow{2}{*}{ Origin } & $0=$ Migrated & $27(39.1)$ & $2(2.9)$ & $3(4.3)$ & $32(46.4)$ & \multirow{2}{*}{$0.000^{* * *}$} \\
\hline & $1=$ Native & $13(18.8)$ & $7(10.1)$ & $17(24.6)$ & $37(53.6)$ & \\
\hline \multirow{2}{*}{ Use of improved rice varieties } & $0=$ No & $32(46.4)$ & $0(0.0)$ & $12(17.4)$ & $44(63.8)$ & \multirow{2}{*}{$0.000^{* * *}$} \\
\hline & $1=$ Yes & $8(11.6)$ & $9(13.0)$ & $8(11.6)$ & $25(36.2)$ & \\
\hline \multirow{2}{*}{ Extension from GOG } & $0=$ No & $31(44.9)$ & $3(4.3)$ & $20(29.0)$ & $54(78.3)$ & \multirow{2}{*}{$0.000^{* * *}$} \\
\hline & $1=$ Yes & $9(13.0)$ & $6(8.7)$ & $0(0.0)$ & $15(21.7)$ & \\
\hline
\end{tabular}




\begin{tabular}{ccccccc}
\hline Extension from NGOs & $0=$ No & $40(58.0)$ & $0(0.0)$ & $20(29.0)$ & $60(87.0)$ & \multirow{2}{*}{$0.000^{* * *}$} \\
& $1=$ Yes & $0(0.0)$ & $9(13.0)$ & $0(0.0)$ & $9(13.0)$ & \\
\hline \multirow{2}{*}{ Networking with neighbors } & $0=$ No & $40(58.0)$ & $9(13.0)$ & $3(4.3)$ & $52(75.4)$ & \multirow{2}{*}{$0.000^{* * *}$} \\
& $1=$ Yes & $0(0.0)$ & $0(0.0)$ & $17(24.6)$ & $17(24.6)$ & \\
\hline Access to credit & $0=$ No & $40(58.0)$ & $0(0.0)$ & $20(29.0)$ & $60(87.0)$ & \multirow{2}{*}{$0.000^{* * *}$} \\
& $1=$ Yes & $0(0.0)$ & $9(13.0)$ & $0(0.0)$ & $9(13.0)$ & \\
\hline
\end{tabular}

$* * *=$ significant at $1 \%, * *=$ significant at $5 \%$ and $*=$ significant $10 \%$.

The mean of farm tools cost per farm area shows higher values for SM and TMR farmers being 78,927 and 59,961 GNF respectively (Table 1). This result confirms again the significant role of income from salt production obtained by SM farmers and the off-farm income from the civil servants belonging to the TMR farmers discussed above. The average of seed quantity of the pooled sample is $74.20 \mathrm{~kg} / \mathrm{acre}$, which is less than the mean seed quantity $(96.24 \mathrm{~kg} / \mathrm{acre})$ used by the SM farmers.

The overall sample shows that only $36 \%$ of farmers used improved rice varieties. This poor adoption of improved rice varieties confirms the result reported by SNSA (2004a), which indicated that $94 \%$ of the cultivated land area utilized local seed in traditional farms, and about $99 \%$ of the plots had no application of pesticides. Sall et al. (1998) stated that the West African agriculture is characterized by high agro-ecological and cultural diversity, limited labor availability and access to agrochemicals, and a strong tradition of self-sufficiency. Consequently, farmers in many areas of West Africa have rejected "modern" varieties of rice developed by formal, science-based institutions for use with inputs such as fertilizer and irrigation water since their local varieties often outperform them.

The research on the development of mangrove rice in West Africa is carried out by the West Africa Rice Development Association (WARDA). Starting in 1976, WARDA maintained a regional rice improvement program in Sierra Leone, targeting approximately 200,000 ha of mangrove swamps cultivated with rice in West Africa. The mangrove rice ecologies, located on tidal estuaries that are near the ocean, are important rice growing environments for six countries in West Africa: Guinea, Guinea Bissau, Senegal, Gambia, Sierra Leone and Nigeria. Seeds of the modern varieties (e.g. ROK-5, ROK-10, etc.) were diffused to Guinea (Zinnah et al., 1993). One of the varieties, ROK-5, has been increasingly adopted. In the Coyah prefecture, it was estimated that the percentage of farmers cultivating ROK-5 increased from $1 \%$ in 1989 to $15 \%$ in 1990 (Adesina \& Zinnah, 1993). On-farm tests conducted from 1982 to 1985 showed that these modern mangrove rice varieties consistently out-yielded the best local varieties by more than 30\% (Agyen-Sampong, 1990).

Mainly, there are two seed systems in Guinea: informal and formal seed systems. (a) The informal seed system supplies the bulk of seed to farmers. From the previous harvest, farmers and local seed dealers to save seed for the next cropping season, and pass it on through barter, gift or sale. The informal seed system provides inexpensive seed thanks to its low production cost. Seed is produced and stored as part of crop production (Richards, 1986). However, a few farmers specialize in seed production (Okry et al., 2011). In Guinea the informal seed system supplies more than $90 \%$ of farmers' seed (SNPRV, 2001). (b) The formal seed system focuses exclusively on improved varieties and commercial crops, such as cotton and cocoa. As the seed production units are located near cities, farmers in remote areas are discouraged from accessing quality seed. Moreover, many are reluctant to pay more than the grain price to buy seed as they are not sure whether the source can be trusted or if they are unaware of the added benefits of the quality seed. From production to sale, formal seed is broken into discrete activities, done by different stakeholders rather than a single farmer, and it is fully regulated by the government.

The extension services provided by the government of Guinea (GOG) shows that among the pooled sample only $22 \%$ of farmers have been assisted. The TMR farmers stated they did not benefit from these services provided by the GOG. But $25 \%$ of these TMR farmers have been assisted by their highly educated neighbors. Access to credit remains extremely low, only 13\% farmers (IMR) stated about having access to credit. A significant fraction of credit transactions in developing countries still takes place in the informal sector, in spite of serious government efforts to channel credit directly via its own banks, or by regulating commercial banks (Hoff \& Stiglitz, 1993). This is largely because poorer farmers lack sufficient assets to put up as collateral, a usual prerequisite for borrowing from banks (Note 7). Numerous case studies and empirical analyses in a variety of countries have revealed that informal credit markets often display patterns and features not commonly found in 
institutional lending.

\subsection{Stochastic Frontier Production and Estimation of Technical Inefficiency}

The stochastic frontier production function and the technical inefficiency estimates of the surveyed mangrove rice farmers in the coastal area of Koba are presented in Table 2. Overall, the production elasticity of mangrove rice production is positive and significant as expected. The stochastic frontier model revealed that only the coefficients of farm area, depreciation cost of farm tools and hired labor cost have the expected positive signs. This implies that these variables have a positive influence on mangrove rice production efficiency. Bringing more farm land under mangrove rice cultivation with more investment on farm tools and hiring labor has the tendency of increasing the technical efficiency of mangrove rice farmers. The coefficient of farm area is positive and significant at the 5\% level. Our results confirm findings from previous studies (Idiong, 2007; Ologbon et al., 2012; Athipanyakul et al., 2014), who also highlight the positive effect of the farm size on the technical efficiency of rice production. The depreciation cost of farm tools is also positive and significant. Despite, the outdated farm tools, the investment on farm tools during one season of rice production has revealed a positive influence on the mangrove rice production efficiency. The implication of this finding suggests that the adoption of machinery could enhance the technical efficiency of mangrove rice production in Guinea. This is in line with a previous study (Akanbi et al., 2011) highlighting the machine use as an important contributor to the improvement of technical efficiency in rice production.

The coefficient of hired labor cost is positive, but not statistically significant. This implies that the investment in labor forces in the mangrove rice production in Koba (Boffa prefecture) does not bring improvement in productivity. Therefore, a previous study (Balde et al., 2014c) related to the technical efficiency measurement in the same study area found that the investment in labor could bring a significant improvement in performance of salt production. In addition, a study (Balde et al., 2013a) on mangrove rice production in the coastal area of Dubreka prefecture, in Guinea also found that among all inputs included under the average variable costs (fertilizer cost, pesticide cost, herbicide cost, hired labor cost, local and improved varieties cost), the hired labor per hectare represented the highest variable input in terms of cost (77 to $97 \%$ of variable cost according the different type of rice varieties under consideration). In Nigeria, where the mangrove rice production is called swamp rice production; Idiong (2007) found that labor use has a positive and significant effect on technical efficiency in this farming system.

Fertilizer and pesticide cost indicated a significant negative value of -0.90 (Table 2). This implies an inverse relationship between these inputs and the output obtained from the mangrove rice production i.e. an increment of the input by $1 \%$ will reduce the total output by $90 \%$. Previous studies (Okoruwa \& Ogundele, 2006; Akanbi et al., 2011) explained the negative value of the fertilizer input as the result of over utilization of this input. Contrarily to their explanations; as regards to our field investigation conducted in the study area, this current research argues that the significant negative value of fertilizer and pesticide could be explained through the poor quality of these inputs. Surveyed farmers stated that the poor quality of these inputs could be attributed to the poor storage system. The main types of inorganic fertilizer were triple 17 and urea. The pesticide was "Roundup". It is also important to highlight that the accessibility of modern farm inputs (fertilizer, agrochemical, improved seed varieties etc.) in the mangrove rice farming system in Guinea remains insignificant. This is well known in the coastal area of Guinea where this mangrove rice production is mainly practiced by small-scale farmers. This is in line with previous studies conducted in the Guinean coastal area. Balde et al. (2013a) found a very low use of the inorganic fertilizer i.e. $92 \%$ of respondents did not apply the inorganic fertilizer. In general, farmers were satisfied with the organic matter, debris brought to the rice plots by the seawater intrusion under the influence of the tides. In addition, a study (Balde et al., 2014a) which examined the role of land use transitions on improving the livelihood of local farmers growing mangrove rice has also revealed the insignificant usage of fertilizer (i.e. $90 \%$ of surveyed farmers did not apply it). This result (Table 2) also confirms the finding by Abdulai and Huffman (2000) that a negative relationship between the use of fertilizer and the level of profit inefficiency in the Northern region of Ghana.

Both seed quantity and active family labors also indicated negative insignificant coefficients. The coefficient of seed quantity and family labors of -0.049 and -0.051 signifies about $5 \%$ decrease in the revenue of mangrove rice production output for every $1 \%$ increase in the quantity of seed and family labor, respectively. However, Ologbon et al. (2012), found that quantity of planted seeds was positively significant depicting an increase in rice output as seeds use is increased.

The maximum likelihood estimates (MLEs) for parameters of the technical inefficiency model are also presented in Table 2. The estimated coefficients of the explanatory variables in the model for the technical inefficiency 
effects are of interest and have important implications as shown in Table 2. A negative sign on a parameter explaining inefficiencies means that the variable is improving technical efficiency, while for a positive sign, the reverse is true. The results indicated that age of household's head, household size, farming experience and off-farm income coupled and remittance are significant determinants of the technical efficiency (negative impact on the technical inefficiency) in the mangrove rice production. However, variables such as education level, usage of improved seed, extension service provided by the Government of Guinea (GOG) and credit, despite their statistical significance levels, impact negatively to the technical efficiency (positively to the technical inefficiency, i.e. Table 2) in mangrove rice production.

The impact of age of the household's head is negatively significant, implying that the older mangrove rice farmers were more productive than the younger ones. This finding confirms the results of previous studies conducted by Idiong (2007), Tijani (2006). However, a study (Balde et al., 2014c) conducted in the same site focusing on the technical efficiency of salt production found that younger salt producers were more efficient than the older ones. With respect to education level, it is significant but has a negative impact (positive impact on the technical inefficiency) to the technical efficiency of the mangrove rice production. This implies that less educated mangrove rice farmers are more efficient than better educated rice farmers. The result is consistent with the study of Idiong (2007), who also found that education level was significant and positively affecting to the technical inefficiency of rice production in Nigeria. This means being an educated mangrove rice farmer was not enough to significantly attain higher levels of efficiency.

The variable household size has a positive and highly significant impact on the efficiency of mangrove rice production. This implies that farmers with more household members perform better than those with fewer members. This result confirms the findings of Rahman et al. (2012), who found that family size had a negative and significant impact on technical inefficiency of rice production. The estimated coefficient of years of experience in mangrove rice farming is negative, conforming to our priori expectation, and it is statistically significant. The implication is that farmers with more experience in rice production are more efficient than the inexperienced ones in the study area. The result is consistent with the work of Bravo-Ureta (1994) who observed positive relationship between economic efficiency and experience in a study of dairy farms. The result also confirms findings from Yiadom-Boakye et al. (2013), who indicated that rice farmers in the Ashanti region of Ghana tend to use the knowledge acquired through experience on soil, and crop management in their farm operations.

The use of improved mangrove rice seed varieties has a negative and significant impact on technical efficiency (positive impact on the technical inefficiency) estimate. This result is in corroboration with the finding of Adesina and Baidu-Forson (1995). They reported that in the case of mangrove rice varieties in Guinea and Sierra Leone, the extension had very little to do with technology diffusion: this occurred mainly through farmers' self-experimentation, evaluation, exchange and transfer. The farmer's self-experimentation is in line with our finding regarding the extension supported by neighboring farmers (discussed below). Extension services from government are significantly and positively related to technical inefficiency. This confirms the results of Muhammad-Lawal et al. (2009), who stated that extension information received by youth participation in agriculture programme in south western Nigeria was positively related to technical inefficiency. Our results are also in line with Raphael (2008) who observed that extension contact has a negative effect on the efficiency of farmers in cassava production. Muhammad-Lawal et al. (2009) argued that this was due to the lack of trust among the participants on the potency of the information received from the extension agents. Moreover, Raphael (2008) was of the opinion that this may be due to bureaucratic inefficiency and some generic weaknesses in information dissemination in the civil service. This weakness of extension services was revealed by Zinnah et al. (1993), who indicated that the researcher-extension-farmer linkages are extremely weak in Guinea and that most of the mangrove rice varieties currently grown by farmers were obtained via farmer-farmer contacts.

The poor effect of agricultural extension programs in farming systems is not surprising. Similar results have been reported in past analyses of the productivity of agriculture in developing countries (Feder et al., 2004). Although agricultural extension and farmer-education programs are key policy instruments for the government seeking to improve the productivity of agriculture, while protecting the environment, yet, many observers document poor performance in the operation of the extension and informal education systems, due to bureaucratic inefficiency, deficient program design, and some generic weaknesses inherent in publicly operated, staff-intensive, information delivery systems. One deficiency highlighted by researchers and practitioners is the tendency of many public officers dealing with the transmission of knowledge to conduct their assignment in a "top-down" manner. Often, the information conveyed is presented as a technological package comprising recommended practices. This is perceived as a less effective method for improving knowledge. In this case, more participatory 
approaches are suggested to extend science-based knowledge and practices (Braun et al., 2002).

Table 2. Estimates of the stochastic frontier and technical inefficiency models of mangrove rice production

\begin{tabular}{|c|c|c|c|}
\hline Variables & Parameters & Coefficient & T-Ratio \\
\hline \multicolumn{4}{|l|}{ Stochastic frontier model } \\
\hline Constant & $\beta_{0}$ & $49.409(3.661)$ & $13.495^{* * *}$ \\
\hline$x_{1}=\operatorname{Ln}($ Fertilizer and pesticide cost $)$ & $\beta_{1}$ & $-0.900(0.215)$ & $-4.187^{* * *}$ \\
\hline$x_{2}=\operatorname{Ln}($ hired labor cost $)$ & $\beta_{2}$ & $0.882(1.849)$ & 0.477 \\
\hline$x_{3}=\operatorname{Ln}($ depreciation cost on farm tools $)$ & $\beta_{3}$ & $0.478(0.195)$ & $2.454^{* *}$ \\
\hline$x_{4}=\operatorname{Ln}($ seed quantity $)$ & $\beta_{4}$ & $-0.049(0.221)$ & -0.220 \\
\hline$x_{5}=\operatorname{Ln}($ active family labors $)$ & $\beta_{5}$ & $-0.051(0.058)$ & -0.869 \\
\hline$x_{6}=\operatorname{Ln}($ farm area in acres $)$ & $\beta_{6}$ & $4.119(1.918)$ & $2.147^{* *}$ \\
\hline \multicolumn{4}{|l|}{ Technical inefficiency model } \\
\hline Constant & $\delta_{0}$ & $3.478(2.292)$ & 1.518 \\
\hline$Z_{1=}$ Age of household head & $\delta_{1}$ & $-0.000(0.000)$ & $-2.328^{* *}$ \\
\hline$Z_{2}=$ Education level & $\delta_{2}$ & $12.654(4.043)$ & $3.130^{* * *}$ \\
\hline$Z_{3}=$ Origin $(1=$ native $; 0=$ migrated $)$ & $\delta_{3}$ & $2.054(1.390)$ & 1.478 \\
\hline$Z_{4}=$ Household size & $\delta_{4}$ & $-7.893(3.368)$ & $-2.343^{* *}$ \\
\hline$Z_{5}=$ Distance to rice field & $\delta_{5}$ & $2.054(1.390)$ & 1.478 \\
\hline $\mathrm{Z}_{6}=$ Farming experience & $\delta_{6}$ & $-10.341(6.061)$ & $-1.706^{*}$ \\
\hline$Z_{7}=$ Usage of improved seed & $\delta_{7}$ & $6.657(3.833)$ & $1.737^{*}$ \\
\hline$Z_{8}=$ Off-farm income and remittance & $\delta_{8}$ & $-4.796(2.563)$ & $-1.871^{*}$ \\
\hline $\mathbf{Z}_{\mathbf{9}}=$ Extension from GOG & $\delta_{9}$ & $8.966(4.702)$ & $1.907^{*}$ \\
\hline$Z_{10}=$ Extension from NGOs & $\delta_{10}$ & $0.739(1.294)$ & 0.571 \\
\hline $\mathrm{Z}_{11}=$ Networking with neighbors for farming advice & $\delta_{11}$ & $-3.746(2.863)$ & -1.308 \\
\hline $\mathrm{Z}_{12}=$ Credit & $\delta_{12}$ & $14.876(7.613)$ & $1.954^{*}$ \\
\hline \multicolumn{4}{|l|}{ Variance parameters } \\
\hline Sigma squared & $\sigma^{2}$ & $79.962(2.252)$ & $35.504^{* * *}$ \\
\hline Gamma & $\gamma$ & $0.464(0.161)$ & $2.876^{* * *}$ \\
\hline Likelihood ratio (LR) test & $\chi^{2}$ & 9.931 & \\
\hline Log likelihood function & & -230.974 & \\
\hline
\end{tabular}

$* * *=$ significant at $1 \%, * *=$ significant at $5 \%$ and $*=$ significant $10 \%$.

Networking with neighbors for farming advice is insignificant and negatively related to the technical inefficiency. This result corroborates with the finding of Adesina and Baidu-Forson (1995), who stated that farmers are important as sources of technology information and agents of technology transfer. When farmers assess the characteristics of new technologies and find them to match their preferences, they often give the technologies to other farmers to test and evaluate thereby setting into motion an endogenous process of technology diffusion.

Access to credit is significant but has a negative impact on the technical efficiency on mangrove rice production. In the other hand, it means that a positive and statistical significance is found between access to credit and technical inefficiency. This implies that accessibility and availability of credit relaxes the production constraints and hence makes it easier to timely purchase of resources thereby increasing productivity through efficiency. This indicates that farmers who have access to credit tend to exhibit higher levels of inefficiency. This is contrary to a priori expectation that the more credit the farmers use, the more efficient they become. It might be as a result of the credit received being misused (or diverted to other uses). The result agrees with the findings of Etim and 
Okon (2013), Baruwa and Oke (2012) and Aye and Mungatana (2010). The negative impact on the technical efficiency of the variable credit mentioned above explained its constraint to farmers. This was also highlighted by Komicha and Öhlmer (2007), who stated credit constraint not only affects the purchasing power of farmers to procure farm inputs and cover operating costs in the short run, but also their capacity to make farm-related investments as well as a risk behavior in technology choice and adoption. These, in turn, have an influence on the technical efficiency of the farmers. Although the credit constraint problem has been recognized in the economics literature, especially in those dealing with developing countries, little emphasis has been given to its effect on productive efficiency of farmers.

The overall technical inefficiency effects are evaluated in terms of the parameters associated with $\sigma^{2}$ and $\gamma$ (Table 2). The estimate for the variance parameters $\sigma$ is significantly different from zero at one percent level (Table 2). This indicates statistical confirmation of our presumption that there are differences in Technical efficiency (TE) among the mangrove rice farmers. The gamma value $(\gamma)$ of the MLEs of stochastic frontier production model is 0.464 (Table 2). This value is statistically significant at the $1 \%$ level, implying that $46 \%$ of variability of revenue from mangrove rice production is attributed to technical inefficiency. And the rest (54\%) is due to random noises. This also confirms that the application of the stochastic frontier function model is appropriate for this study.

Moreover, the presence of technical inefficiency was tested by the Likelihood Ratio (LR) test. The null hypothesis $\left(\mathrm{H}_{0}\right)$ implies that gamma value is equal to zero. In other words, variations of mangrove rice production revenue are due to random noises or stochastic frontier model is inadequate. Alternative hypothesis $\left(\mathrm{H}_{1}\right)$ implies that gamma value is different from zero or the application of the stochastic frontier model is adequate. LR test has a mixed chi-square $\left(x^{2}{ }_{R}\right)$ distribution with $\mathrm{R}$ equal to restrictions in the model. According to statistic principles, the null hypothesis $\left(\mathrm{H}_{0}\right)$ will be rejected if LR test is greater than critical chi-square value table. Table 2 shows that LR value is 9.93; and the critical chi-square value $\left(x^{2}{ }_{(1 \%, R)}\right)$ is equal to 16.07 (obtained from Kodde \& Palm, 1986). Hence, LR test is less than critical chi-square value. Therefore, the null hypothesis $\left(\mathrm{H}_{0}\right)$ is accepted. Tests of null hypotheses associated with the models were carried out using the likelihood ratio (LR) statistics and the results are presented in Table 3. The first null hypothesis $\left(H_{0}: \gamma=\delta_{0}=\right.$ $\cdots=\delta_{12}=0$ ) that inefficiency is absent from the model, is strongly accepted. This implies that the mean response function is an adequate representation of the data for the mangrove rice production. The second null hypothesis $\left(H_{0}: \gamma=0\right)$ which specifies that the inefficiency effects are not stochastic, is accepted. So, we do accept the null hypothesis that there was technical inefficiency. The parameter $\gamma$ is estimated to be 0.464 (Table 2) indicating that $46.4 \%$ of inefficiency is due to the mangrove rice farmer's own decision and the remaining $54 \%$ is due to the factors outside the control of the farmers. The parameter $\gamma$ also reflects that the inefficiency effects are highly significant in the analysis of mangrove rice production (Table 2).

The third null hypothesis considered in the model $\left(H_{0}: \delta_{0}=\cdots=\delta_{12}=0\right)$ that the coefficients of the explanatory variables in the inefficiency models are simultaneously zero, is also accepted. This indicates that all twelve explanatory variables considered in the model (Equation 2) did not make a significant contribution in the explanation of inefficiency effects associated with the value of output. The last null hypothesis considered $\left(H_{0}: \delta_{1}=\cdots=\delta_{12}=0\right)$ that the coefficients of the variables in the model for inefficiency effects are zero, is also accepted. It reflects that all the coefficients of the explanatory model are not significantly influenced by the variables (Equation 2 or Table 2).

Table 3. Generalized likelihood ratio (LR) tests

\begin{tabular}{|c|c|c|c|c|}
\hline Null hypotheses & Log likelihood & $\operatorname{LR}(\lambda)$ & Critical value & Decision \\
\hline $1 . \mathrm{H}_{0}: \gamma=\delta_{0}=\ldots \delta_{12}=0$ & -0.104 & -461.74 & 16.07 & Accept $\mathrm{H}_{0}$ \\
\hline 2. $\mathrm{H}_{0}: \gamma=\mathbf{0}$ & -241.95 & 21.95 & 25.55 & Accept $\mathrm{H}_{0}$ \\
\hline 3. $\mathrm{H}_{0}: \delta_{0}=\ldots \delta_{12}=0$ & -0.104 & -461.74 & 5.41 & Accept $\mathrm{H}_{0}$ \\
\hline 4. $H_{0}: \delta_{1}=\ldots \delta_{12}=0$ & 48.96 & -559.87 & 16.07 & Accept $\mathrm{H}_{0}$ \\
\hline
\end{tabular}

\subsection{Technical Efficiency Distribution in Mangrove Rice Production}

The result derived from the ML estimates show technical efficiency (TE) indices range from 0.00 to 1.00 with a mean value of 0.23 (Table 4). This means that for an average efficient mangrove rice farmer to achieve the technical efficiency level of its most efficient counterpart, he should realize about $(1.00-0.23 / 1.00)$ savings in 
cost or increase in production. This gives about $77 \%$ increase in production or cost saving. The least efficient mangrove rice farmer can now save a cost or increase in production of $100 \% .(1.00-0.00 / 1.00)$ to achieve the required technical efficiency of the most efficient producers in the study sample. The variation in technical efficiency ( 0.00 to 1.00$)$ of these mangrove rice farmers might arise from managerial decisions and specific-farm characteristics that affect the ability of the farmer to adequately use the existing technology. This explains the reason why three farmers $(4.35 \%)$ have very high technical efficiencies.

To provide a better indication of the distribution of TE, a frequency distribution of the predicted TE is presented in Table 4 . Among the mangrove rice farmers $91.31 \%$ are producing at less than $41 \%$ efficiency level while only $4.35 \%$ of farmers have TE of above $81 \%$, which is an indication that most of mangrove rice farmers (TMR, IMR and SM) still remain inefficient. Efficiency is one of the main factors determining competitiveness. The higher the degree of efficiency the lower will be the unit cost of production and as a result, mangrove rice farmers would be able to produce at lower prices. Consequently, more efficient mangrove rice farmers would have better chances of surviving and prospering in the future than less efficient ones. Along these lines, analysis of efficiency would provide information about the potential sources of inefficiency. In addition, measures of potential cost savings that can be achieved from improvements in technical and allocative efficiencies could be derived and used by mangrove rice farmers as a benchmark to improved competitiveness.

Table 4. Frequency distribution of technical efficiency estimates

\begin{tabular}{lll}
\hline Efficiency level (\%) & $\begin{array}{l}\text { Frequency of } \\
\text { rice farmers }\end{array}$ & $\begin{array}{c}\text { mangrove } \\
\text { Percentage of mangrove } \\
\text { rice farmers }\end{array}$ \\
\hline $\mathbf{0 0}-\mathbf{2 0}$ & 33 & 47.83 \\
$\mathbf{2 1 - \mathbf { 4 0 }}$ & 30 & 43.48 \\
$\mathbf{4 1 - 6 0}$ & 3 & 4.35 \\
$\mathbf{6 1 - \mathbf { 8 0 }}$ & 0 & 0.00 \\
$\mathbf{8 1}-\mathbf{1 0 0}$ & 3 & 4.35 \\
Total & 69.00 & 100.00 \\
Mean efficiency & 0.23 & \\
Minimum & 0.00 & \\
Maximum & 1.00 & \\
\hline
\end{tabular}

\subsection{Loss Due to Inefficiency and Potential Output of Mangrove Rice Production}

In order to measure the loss due to inefficiency, both actual output and potential outputs were calculated first (Mor \& Sharma, 2012). The potential output as well as loss of output is estimated by dividing the actual output by the mean technical efficiency, whereas the output forgone (loss due to inefficiency) is the difference between the potential output and the actual output (Mor \& Sharma, 2012). Table 5 presents an account of the potential as well as the output forgone in mangrove rice production in the study area. Mangrove rice farmers on average loose output worth of $8,838,762$ Guinean francs per acre (GNF/acre) seasonally solely due to the technical inefficiency. This can be regained by way of better utilization of resources which are at the disposal of the mangrove rice farmers.

As highlighted in Balde et al. (2014c), there are three possible ways to increase mangrove rice production in the coastal area of Guinea. Firstly, by allocating more land, secondly by developing and adopting new technologies and thirdly by utilizing the available resources more efficiently. The third option of using available resources more efficiently is the most viable approach. This implies that increased mangrove rice growing hinges upon the improvement of productivity, i.e. yield per unit area. According to Abedullah et al. (2007), it is generally believed that resources in the agricultural sector, especially in the developing countries are being utilized inefficiently. Farmers are mainly concerned with the profitability of farming business which directly or indirectly depends on resource use efficiency.

Productivity growth can be achieved either through technological change (development and adoption of new technologies) or improvement in technical efficiency (ability to obtain maximum output from a given input mix and the existing technology) but the most cost-effective strategy depends on the magnitudes of the inefficiencies 
(Dey et al., 2000). When producers are highly efficient, the former is applicable, however if inefficiencies are large the latter is likely the most cost-effective means of raising productivity.

Table 5. Estimated potential output and output for mangrove rice production

\begin{tabular}{ll}
\hline Technical efficiency & Mangrove rice producers \\
\hline Actual output (GNF/acre) & $2,640,149.54$ \\
Potential output (GNF/acre) & $11,478,911.04$ \\
Loss due to inefficiency (GNF/acre) & $8,838,761.50$ \\
\hline
\end{tabular}

\section{Conclusion and Policy Considerations}

This paper used stochastic frontier production function to measure technical efficiency of mangrove rice farmers in the coastal area of the Koba sub-prefecture in Guinea. Among the inputs incorporated into the Cobb-Douglas production function, results revealed that only the farm area and the depreciation cost of farm tools have contributed to the performance of the mangrove rice production. The farm-specific variables used to explain inefficiencies indicate that elderly mangrove rice farmers with farming experience, significant household size and access to off-farm income and remittance tend to be more efficient. However, education level, improved seed use, extension services provided by the government and access to credit have a negative influence on technical efficiency in this mangrove rice farming system. Overall, this study revealed a wide variation in the level of technical efficiency of mangrove rice farmers with an average of $23 \%$. Thus, the mangrove rice production in the coastal area of Koba has a potential to be increased by $77 \%$, if prevailing inefficiencies are overcome, without increasing the level of inputs. Furthermore, the loss due to the inefficiency was enormously significant at 8,838,762 Guinean Francs per acre for the whole season of mangrove rice production.

Based on the findings, policy implications are advocated. The technical efficiency can be improved by focusing on farm area and farm tools. Higher technical efficiency can be achieved through the irrigation which leads to boost the productivity of mangrove rice and preserve the mangrove forest from slashing new stand of it for the extent of farm area. The restoration of abandoned rice fields favors farmers with less farm area to increase their extents. The role of farm tools in increasing efficiency of mangrove rice production suggests a possibility for a small-scale mechanization in this farming system. The government is required to facilitate the public investment in physical infrastructure (irrigation including embankments, dikes, etc.) which is crucial for improving mangrove rice farmers' efficiency, and then, earnings. Irrigation schemes are a sustainable alternative which can contribute to preserving the fragile mangrove ecosystem through deforestation.

In addition, age of household head, family size, off-farm income and remittance as well as farming experience are important policy variables and determinants of efficiency, which can be considered in formulating agricultural policy in Guinea in order to raise the current level of technical efficiency and hence the level of productivity in the mangrove rice sector. This could be possible if the government involves in creating job opportunities directly or indirectly in order to improve the revenue from off-farm income. As the remittance is almost transferred by family members living in cities or abroad, this creation of job opportunities could also stabilize the household members from migration. The people of West Africa have a long tradition of mobility. Evidence suggests that one in three individuals no longer resides in their place of birth (De-Haan, 2000). Migration has been described as the history of the peoples' struggle to survive and to prosper, to escape the insecurity and poverty, and to move in response to opportunity (DFID, 2004). The findings also advocate strategies for the reduction of inefficiency in this farming system by enhancing the farmers' education level through extension programs and providing enough inputs (credit, improved seed varieties, fertilizer and pesticide). These recommendations will pave the way to mitigate the significant loss due to the inefficiency occurring seasonally in the mangrove rice production system.

As with any research, this study too had certain limitations. Studies on the technical efficiency of mangrove rice production in Guinea were not available for the purpose of comparison and discussions with our results. Due to the lack of empirical data related to mangrove rice production in the coastal zone of Guinea, this paper did not focus on the background detail of mangrove rice production in the study area. Since the empirical results are based on relatively limited sample size, the findings should not be generalized. To enhance the generalizability of the results, further scrutiny through theoretical and empirical studies is required. 


\section{References}

Abdulai, A., \& Huffman, W. (2000). Structural adjustment and economic efficiency of Rice Farmers in Northern Ghana. Econ. Dev. Cult. Change (pp. 504-519).

Abedullah, Kouser, S., \& Mushtaq, K. (2007). Analysis of technical efficiency of rice production in punjab (Pakistan): Implications for future investment strategies. Pakistan Economic and Social Review, 45(2), 231-244.

Adesina, A. A., \& Baidu-Forson, J. (1995). Farmers' perceptions and adoption of new agricultural technology: evidence from analysis in Burkina Faso and Guinea, West Africa. Agricultural Economics, 13, 1-9. http://dx.doi.org/10.1016/0169-5150(95)01142-8

Adesina, A. A., \& Zinnah, M. M. (1993). Impact of modern mangrove swamp rice varieties in Sierra Leone and Guinea. Int. Rice Res. Notes, 18, 36.

Agyen-Sampong, M. (1990). History of rice research in Rokupr: Evaluation and overview of WARDA's mangrove rice program, and relationship to national program. West Africa Rice Development Association, Rokupr, Sierra Leone.

Aigner, D., Lovell, C. A. K., \& Schmidt, P. (1977). Formulation and Estimation of Stochastic frontier production models. Journal of Econometrics, 6, 21-37.

Akanbi, U. O., Omotesho, O. A., \& Ayinde, O. E. (2011). Analysis of technical efficiency of rice farms in duku irrigation scheme kwara state, Nigeria. Nigerian Journal of Agriculture, Food and Environment, 7(3), 65-72.

Athipanyakul, T., Jitsaeng, P., Pongkapan, N., \& Pakdee, P. (2014), Key factors for improving technical efficiency of upland rice production. American Journal of Applied Sciences, 11(2), $266-272$. http://dx.doi.org/10.3844/ajassp.2014.266.272

Aye, G. C., \& Mungatana, E. D. (2010). Technical efficiency of traditional and hybrid maize farmers in Nigeria: Comparison of alternative approaches. Afr. J. Agric. Res., 5(21), 2909-2917.

Bakhsh, K., Ahmad, B., \& Hassan, S. (2006). Food security through increasing technical efficiency. Asian J. Plant Sci., 5, 970-976.

Balde, B. S., Kobayashi, H., Matsumura, I., Nohmi, M., Esham M., \& Tolno, E. (2013a). Present Status and Determinants of Mangrove Rice Production in Dubreka prefecture in Guinea. Japanese Journal of Farm Magement, 51(3), 97-102.

Balde, B. S., Kobayashi, H., Nohmi, M., Ishida, A., Matsumura, I., Esham, M., \& Tolno, E. (2013b). Socio-Economic Analysis of small-scale salt production techniques in the coastal area of Guinea: An alternative for improving livelihood status and mangrove forest management. International Journal of Research in Engineering, IT and Social Science, 3(9), 1-23. Retrieved from http://www.indusedu.org/IJREISS/September2013(pdf)/1.pdf

Balde, B. S., Kobayashi, H., Matsumura, I., Esham, M., Alam, A., \& Tolno, E. (2014a). Land use changes and their determinants in the coastal area of Guinea: A study based on spatial and field survey. Journal of the Japanese Agricultural Systems Society, 30(3), July 2014 (In press).

Balde, B. S., Kobayashi, H., Ishida, A., Nohmi, M., Esham, M., Matsumura, I., \& Tolno, E. (2014b). Effects of rural livelihood activities on income inequality and poverty reduction in the Guinean coastal area. Journal of Agricultural Science, 6(6), 113-130. http://dx.doi.org/10.5539/jas.v6n6p113

Balde, B. S., Kobayashi, H., Nohmi, M., Ishida, A., Matsumura, I., Esham, M., \& Tolno, E. (2014c). A stochastic frontier approach for measuring technical efficiency of small-scale salt production in Guinea. American Journal of Applied Sciences, 11(8), 1310-1320. http://dx.doi.org/10.3844/ajassp.2014.1310.1320

Bamiro, O. M., Phillip, D. O. A., \& Momoh, S. (2006). Vertical integration and technical efficiency in poultry (Egg) industry in Ogun and Oyo states, Nigeria. Int. J. Poult. Sci., 5, 1164-1171.

Baruwa, O. I., \& Oke, J. T. O. (2012). Analysis of the technical efficiency of small-holder cocoyam farms in Ondo state, Nigeria. Tropicultura, 30(1), 36-40.

Barry, B. M. (2006). Diversité et dynamique des variétés locales de riz (O. sativa et O. glaberrima) en Guinée. Conséquences pour la conservation des ressources génétiques. $\mathrm{PhD}$ thesis, Ecole Nationale Supérieure Agronomique de Rennes, Rennes, France. 
Battese, G., \& Coelli, T. (1995). A model for technical inefficiency effects in a stochastic frontier production function for panel data. Empirical Economics, 20, 325-332.

Binuomote, S. O., Ajetomobi, J. O., \& Ajao, A. O. (2008). Technical efficiency of poultry egg producers in Oyo state of Nigeria. Int. J. Poult. Sci., 7, 1227-1231.

Braun, A., Thiele, G., \& Fernandez, M. (2002). Farmer field schools and local agricultural research committee: complementary platforms for integrated decision-making in sustainable agriculture. ODI, Agricultural Research and Extension, Network Paper 105.

Bravo-Ureta, B. E., \& Evenson, R. E. (1994). Efficiency in Agricultural Production, the Case of Peasant Farmers in Eastern Paraguay. Agric. Econ., 10, $27-37$.

Carr, S. (2013). African Agriculture: Does farm size really matter? Retrieved from http://wle.cgiar.org/blogs/2013/02/07/african-agriculture-does-size-really-matter/

CEC. (1992). The Mangroves of Africa and Madagascar. Office for Official Publications of the European Communities (CEC), Luxembourg (p. 273). In M. Sylla (Ed.), Soil salinity and acidity: Spatial variability and effects on rice production in West Africa's Mangrove zone (pp. 175). PhD Thesis, Wageningen.

Coelli, T. (1996). A guide to FRONTIER version 4.1: A computer program for stochastic frontier production and cost function estimation. CEPA working paper 96/97, Department of Econometrics, University of New England, Armidale, Australia.

Coelli, T., \& Battese, G. (1996). Identification of factors which influence the technical inefficiency of Indian farmers. Australian Journal of Agricultural Economics, 40(2), 103-128.

Coelli, T., Rao, D. S. P., \& Battese, G. E. (1998). An introduction to efficiency and productivity analysis. Kluwer Academic Publishers, Boston, Dordrecht and London.

Danquah, M., Barimah, A., \& Ohemeng, W. (2013). Efficiency Measurement Using a "True" Random Effects and Random Parameter Stochastic Frontier Models: An Application to Rural and Community Banks in Ghana. Modern Economy, 4(12), 864-870. http://dx.doi.org/10.4236/me.2013.412093

De-Haan A. (2000). Migrants, livelihoods and rights: the relevance of migration in development policies. Social Development Working Paper No. 4. February 2000, Social Development Department, Department for International Development (DFID), UK; 2000. Retrieved from http://www.dfid.gov.uk/Documents/publications/sddwp4.pdfS

Dey, M. M., Paraguas, F. J., Bimbaa, G. B., \& Regaspi, P. B. (2000). Technical efficiency of tilapia growth out pond operations in the Philippines. Aquaculture Economics and Management, 4, 33-46.

DFID. (2004). Migration and development: how to make migration work for poverty reduction. House of commons (HC79-I). Sixth Report of Session 2003-04 (Vol. 1). Retrieved from http://www.parliament.uk/parliamentary_com mittees/international_development.cfm

Diawara, S., Conde, A., \& Diallo, B. (2011). Analysis of the competitiveness of local rice in Guinea. Michigan State University, PRESAO (in French).

Etim, N. A., \& Okon, S. (2013). Sources of technical efficiency among subsistence maize farmers in Uyo, Nigeria. Discourse Journal of Agriculture and Food Sciences, 1(4), 48-53.

Feder, G., Murgai, R., \& Quizon, J. B. (2004). Sending farmers back to school: the impact of farmer field schools in Indonesia. Review of Agricultural Economics, 26(1), 45-62.

GRG [Government of the Republic of Guinea]. (2002). National Strategy and Action Plan for Biological Diversity. CBD Strategy and Action Plan - Guinea Part 1, English version. Retrieved from http://www.biodiv.org/doc/world/gn/gn-nbsap-01-p1-en.doc

Hoff, K., \& Stiglitz, J. (1993). Imperfect Information in Rural Credit Markets: Puzzles and Policy Perspectives. In K. Hoff, A. Braverman, \& J. Stiglitz (Eds.), The Economics of Rural Organization: Theory, Practice and Policy. London: Oxford University Press (for the World Bank).

Idiong, I. C. (2007). Estimation of farm level Technical Efficiency in Small-scale Swamp Rice Production in Cross river state of Nigeria: A stochastic frontier Approach. World Journal of Agricultural Sciences, 3(5), 653-658.

Kodde, D. A., \& Palm, F. C. (1986). Wald Criteria for Jointly Testing Equality and Inequality Restrictions. Econometrica, 54(5), 1243-1248. 
Komicha, H. H., \& Öhlmer, B. (2007). Influence of Credit Constraint on Technical Efficiency of Farm Households in Southeastern Ethiopia. International Conference on African Development Archives. Paper 125. Retrieved from http://scholarworks.wmich.edu/africancenter_icad_archive/125

MAEF. (2007a). Politique nationale de développement agricole vision 2015 (Vol. 1). Bilan-Diagnostic de la LPDA2 (1998-2005). Ministère de l'Agriculture des Eaux et Forêts, Conakry.

MAEF. (2007b). Nouvelle vision de l'agriculture Guinéenne. Politique nationale de développement agricole vision 2015 (Vol. 2). Orientations et axes stratégiques. Ministère de l'Agriculture des Eaux et Forêts, Conakry.

MAL [Ministry of Agriculture and Livestock]. (2009) National strategy for the development of rice growing, Republic of Guinear Retrieved from http://www.jica.go.jp/english/our_work/thematic_issues/agricultural/pdf/guinea_en.pdf

Mor, S., \& Sharman, S. (2012). Technical efficiency and supply chain practices in dairying: The case of India. Agric. Econ. (Czech), 58(2), 85-91.

Muhammad-Lawal, A., Omotesho, O. A., \& Falola, A. (2009). Technical efficiency of youth participation in agriculture: a case study of the youth - in - agriculture programme in ondo state, south western Nigeria. Nigerian Journal of Agriculture, Food and Environment, 5(1), 20-26.

Okoruwa, V. O., \& Ogundele, O. O. (2006). Technical Efficiency Differentials in Rice Production Technologies in Nigeria. Agric Research Paper 134. African Economic Research Consortium, Nairobi.

Okry, F., Van Mele, P., Nuijten, E., Struik, P. C., \& Mongbo, R. L. (2011). Organizational analysis of the seed sector of rice in Guinea: stakeholders, perception and institutional linkages. Experimental Agriculture, 47(1), 137-157. http://dx.doi.org/10.1017/S001447971000089x

Ologbon, O. A. C., Ikheloa, E. E., \& Akerele, E. O. (2012). Adoption of 'Ofada' Rice Variety and Technical Efficiency of Rice-Based Production Systems in Ogun State, Nigeria. World Journal of Agricultural Sciences, 8(6), 624-631.

Orea, L., \& Kumbhakar, S. C. (2004). Efficiency measurement using a latent class stochastic frontier model. Empirical Economics, 29, 169-183. http://dx.doi.org/10.1007/s00181-003-0184-2

Portères, R. (1966). Les noms des riz en Guinée. Journal d'Agriculture Tropicale et de Botanique Appliqué, 13, 346.

Rahman, K. M. M., Mia, M. I. A., \& Bhuiyan, M. K. J. (2012). A Stochastic Frontier Approach to Model Technical Efficiency of Rice Farmers in Bangladesh: An Empirical Analysis. The Agriculturists, 10(2), 9-19.

Raphael, I. O. (2008). Technical Efficiency of Cassava farmers in South Eastern Nigeria: Stochastic Frontier Approach. Medwell On Line Agricultural Journal, 3(2), 152-156. Retrieved from http://www.medwelljournals.com/fulltext/aj/2008/152-156.pdf on the 6th November, 2008

Richards, P. (1986). Coping with Hunger: Hazard and Experiment in an African Rice-farming System. Allen and Unwin, London.

Sall, S., Norman, D., \& Featherstone, A. (1998). Adaptability of improved rice varieties in Senegal. Agricultural Systems, 57(1), 101-114.

SNPRV. (2001). Multiplication and Diffusion of Community-based Seeds of NERICA Rice Developed by WARDA. Agence Nationale de Promotion et de Conseil Agricole, Conakry.

SNSA [Service National des Statistiques Agricoles]. (2004a). Recensement National de l'Agriculture (RNA: 2000/2001). Service National des Statistiques Agricoles/République de Guinée (Volume II: Rapport Annexe, p. 265).

SNSA [Service National des Statistiques Agricoles]. (2004b). Recensement National de l'Agriculture (RNA: 2000/2001). Service National des Statistiques Agricoles/République de Guinée (Volume I: Principaux résultats, p. 94).

Tijani, A. A. (2006). Analysis of the technical efficiency of rice farms in Ijesha Land of Osun State, Nigeria. Agrekon, 45(2), 126-135. http://dx.doi.org/10.1080/03031853.2006.9523738

Yiadom-Boakye, E., Owusu-Sekyere, E., Nkegbe, P. K., \& Ohene-Yankyera, K. (2013). Gender, resource use and technical efficiency among rice farmers in the Ashanti Region, Ghana. Journal of Agricultural 
Economics and Development, 2(3), 102-110.

Zinnah, M. M., Compton, J. L., \& Adesina, A. A. (1993). Research-extension-farmer linkages within the context of the generation, transfer and adoption of improved mangrove swamp rice technology in West Africa. $Q$. $J$. Int. Agric., 32, 201-211.

\section{Notes}

Note 1. TMR farmers practiced the traditional mangrove rice cultivation in Makinsi district and the only improved area was the large abandoned basins of shrimp farming. According to Balde et al. (2014a), the traditional mangrove rice farms (TMRF) are enclosed by small embankments constructed by the farmers. They make ridges in the plots where rice is planted, to control the inflow of sea water and protect the rice field from crabs. Often palm tree trunks, and occasionally pipes, are used for the drainage systems.

Note 2. IMR farmers practiced the improved mangrove rice farming (IMRF) in the district of Bentya. These irrigated perimeters developed by the government are surrounded by a large embankment preventing the intrusion of sea water into the rice fields. These fields are separated by dikes and flood gates. Thus, during the dry season, the sea water intrusion allows for weed control and to prevent soil acidification, and during the cropping season, the gates remain closed to prevent sea water intrusion into the rice fields.

Note 3. SM producers are both improved salt producers and improved mangrove rice farmers. In this study, we included them by considering only the aspect of the mangrove rice production. Salt marsh (SM) production was practiced along the coastline of Balessourou including Pompage sector in Koba. This area was separated from the improved area of mangrove rice farming by a large embankment, which also serves as a route connecting Balessourou to Kindiady, another fishing port and mangrove wood market. This proximity of the salt production area and improved zone of mangrove rice farming could explain the involvement of Salt Marsh (SM) producers in both activities. In addition, saving of time due to the adoption of improved salt production is another reason. Balde et al. (2013b) reported that the saving time due to improved salt production enable SM producers to earn a profit from the mangrove rice production. For further details about these techniques of salt production in the Guinean coastal area refer to (Balde et al., 2013b).

Note 4. Stephen Carr has spent sixty years working with small-scale farmers in a range of African countries, both at the village level and in senior positions with African governments and internationally.

Note 5. It refers to the second Agricultural Census in Guinea, conducted during the year 2000/2001. Prior to this one, Guinea had conducted another census during the year 1988/1989. The Census was organized by the National Service of Agricultural Statistics (Ministry of Agriculture, Livestock, Water and Forest), with assistance from FAO, USDA and World Bank. The preparatory phase for census lasted during 1999/2000. Fieldwork for data collection was carried out during 2000/2001. The data were processed during March-December 2003. Reports on Recensement National de l'agriculture, Campagne agricole 2000-2001 were published by the National Service of Agricultural Statistics (Ministry for the Agriculture, Livestock, Water and Forest, Republic of Guinea), on May 2004.

Note 6. The SAKOBA shrimp farm was established in 1995 and the production was shut down in 1999. This industrial farm built by the Guinean Government included 400 hectares of ponds with a processing plant and hatchery which did not produce more than 250 tons. Among the serious problems of poor management and the choice of an unadaptable site- production has never been operational to date. A large scale hatchery was located on the isolated island of Tamara, offshore of Conakry, while the farm was located over two hours by road up the coast of Guinea in the region of Koba. From its inception, the project was plagued by cost over-runs and poor management. These problems were compounded by logistical issues (proximity of the two integral facilities), and unmanageable technical problems (acid soil, and silted water on the farm).

Note 7. Banks, in turn, have to rely on such guarantees because the impersonal nature of institutional lending reduces the ability to select or monitor borrowers effectively.

\section{Copyrights}

Copyright for this article is retained by the author(s), with first publication rights granted to the journal.

This is an open-access article distributed under the terms and conditions of the Creative Commons Attribution license (http://creativecommons.org/licenses/by/3.0/). 